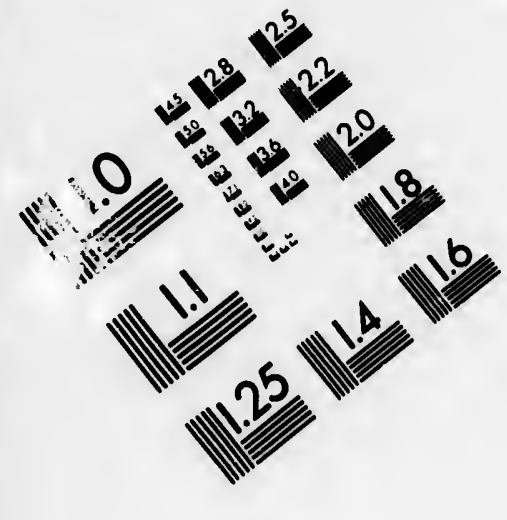

IMAGE EVALUATION

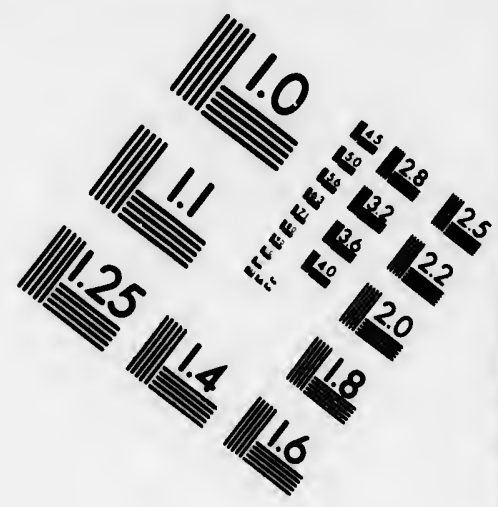

TEST TARGET (MT-3)
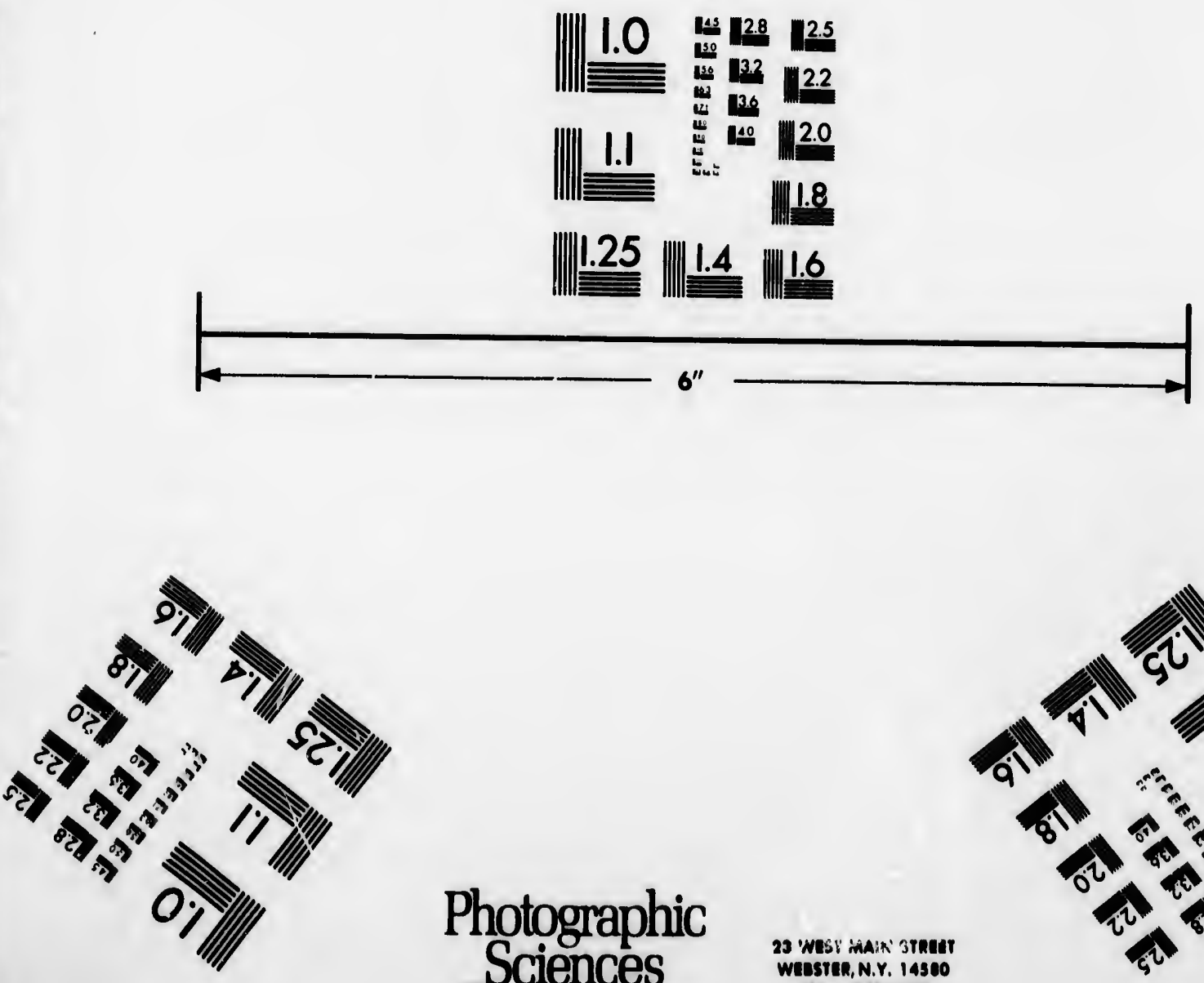

Photographic Sciences Corporation
23 'MSEY MAIN 3TRut WLasten, N.Y. 14560

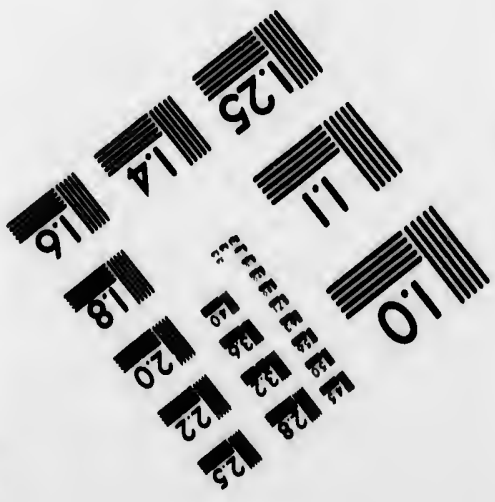




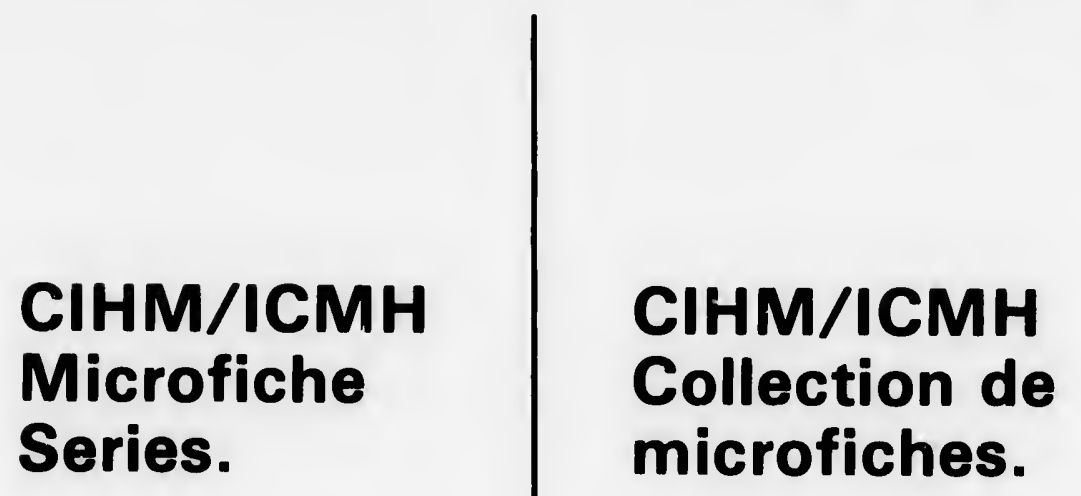

Canadian Institute for Historical Microreproductions / Institut canadien de microreproductions historiques
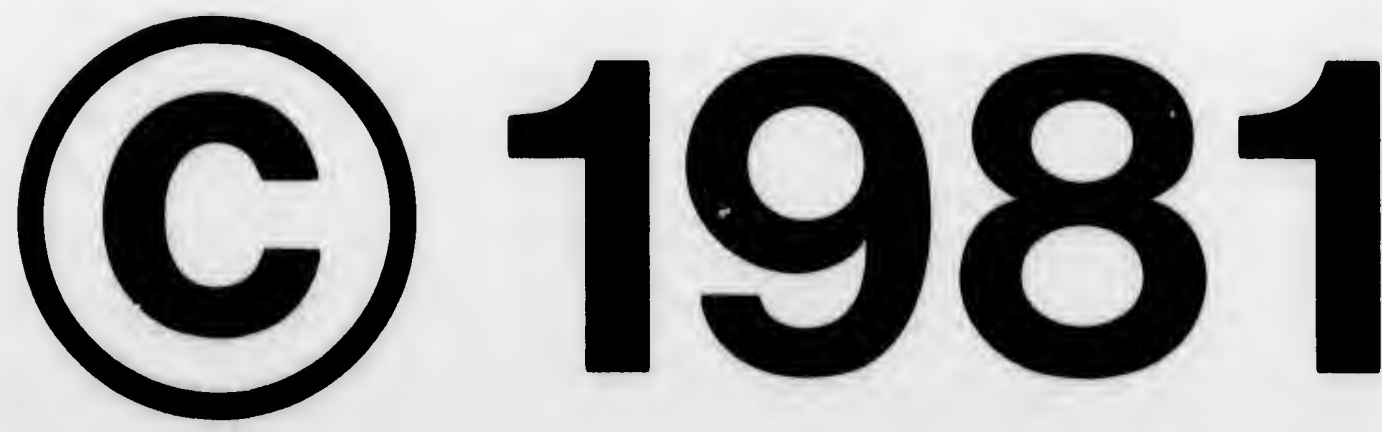
The Institute has attempted to obtain the best original copy available for filming. Features of this copy which may be bibliographically unique, which may alter any of the images In the reproduction, or which mey significently change the usual method of filming, are checked below.

Coloured covers/

Couverture de couleur

Covars damaged/

Couverture endommagée

Covers restored and/or laminated/

Couverture restaurbe et/ou pelliculé

Cover title missing/

Le titre de couverture manque

Coloured maps/

Cartes géographiques en couleur

Coloured ink (i.e. other than blue or black)/

Encre de couleur (i.e. autre que bleue ou noire)

Coloured plates and/or illustrations/

Planches et/ou illustrations en couleur

Bound with other material/

Relié avec d'autres documents

Tight binding may cause shadows or distortion along interior margin/

La reliure serrée peut causer de l'ombre ou de la distortion le long de la marge intórieure

Blank leaves added during restoration may eppear within the text. Whenever possible, these have been omitted from filming/

II se peut que certaines pages blenches ajoutdes lors d'une restauration apparaissent dens le texte. mais, lorsque cele otait possible, ces peges n'ont pas été filmós.

\section{Additional comments:/}

Commentaires supplementaires:

L'Institut a microfilme le meilleur exemplaire qu'il lui a été possible de 80 procurer. Les détails de cet exemplaire qui sont peut-être uniques du point de vue bibliogrephique, qui peuvent modifier une image reproduite, ou qui peuvent exiger une modification dans la mbthode normale de filmage sont indiqués ci-dessous.

Coloured pages/

Pages de couleur

Pages damaged/

Pages endommagées

Pages restored and/or laminated/

Pages restaurées et/ou pelliculées

Pages discoloured, stained or foxed/

Pages décolorées, tachetées ou piquées

Pages detached/

Peges détachées

\section{Showthrough/}

Transperence

Quality of print varies/

Qualité inégale de l'impression

Includes supplementary material/

Comprend du matériel supplémentaire

Only edition evailable/

Seule odition disponible

Pages wholly or partially obscured by errata slips, tissues, etc., have been refilmed to ensure the best posslble image/ Les pages totalement ou partiellement obscurcies par un feulllet d'errate, une pelure. etc., ont dtó filmbes b nouveau de façon obtenir la meilleure image possible.

This item is filmed at the reduction ratio checked below/ Ce document est filmo au teux de roduction indique cl-dessous.

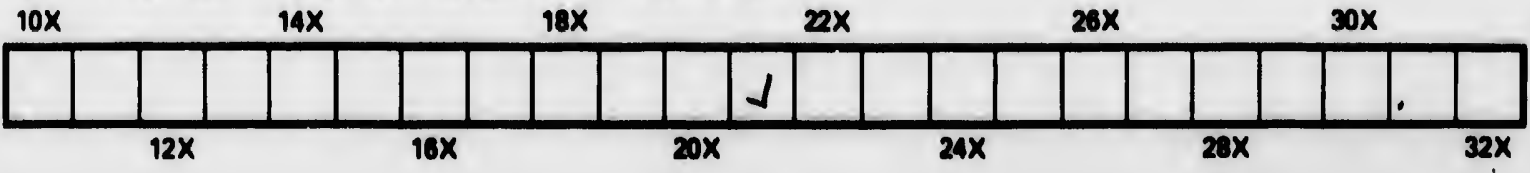


The copy filmed hare has been reproduced thanks to the generosity of:

\section{Entomology Research Library Agriculture Canada}

The images appearing here are the best quality possible considering the condition and leglbility of the original copy and in keeping with the filming contract specifications.

Original copies in printed paper covers are filmed beginning with the front cover and ending on the last page with a printed or illustrated impression, or the back cover when appropriate. All other original copies are filmed beginning on the first page with a printed or illustrated impression, and ending on the last page with a printed or illustrated impression.

The last recorded frame on each microfiche shall contain the symbol $\rightarrow$ Imeaning "CON. TINUED"), or the symbol $\nabla$ (meaning "END"), whichever applles.

Maps, plates, charts, etc., may be filmed at different reductlon ratlos. Those too large to be entirely included in one exposure are filmed beginning in the upper left hand corner. loft to right and top to bottom, as many frames as required. The following diagrams illustrate the method:
L'exemplaire filmó fut reproduit grâce da la gónérosité de:

Bibliothdque de recherche entomologique Agriculture Canada

Les images suivantes ont btל reproduites avac le plus grand soin, compte tenu de la condition ot de la netteté de l'axemplaire filmo, ot on conformité avec les conditions du contrat de filmage.

Les exemplaires oiginaux dont la couverture en papier est imprimbe sont filmb́s on commençent per le premiar plat et en terminant soit par la derniere page quil comporte une empreinte d'impression ou d'illustration, soit par le second plat, solon lo cas. Tous las autres exemplaires originaux sont filmes en commençant par la premiòre page qul comporte une empreinte d'impression ou d'illustration et en terminant par la derniòre page qui comporte une telle empreinte.

Un des symboles sulvants apparaitre sur la dernière image de chaque microflche, selon le cas: le symbole $\rightarrow$ signifie "A SUIVRE", le symbole V signifie "FIN".

Les certes, planches, tableaux, etc., peuvent otre filmós des teux de réduction différente. Lorsque le document est trop grand pour etre reproduit on un saul clichb, II est filmb partir de l'angle superieur gauche, de gauche droite, et de haut en bas, on prenant le nombre d'Imeges nócessalre. Les diegrammes suivants illustrent la móthode.
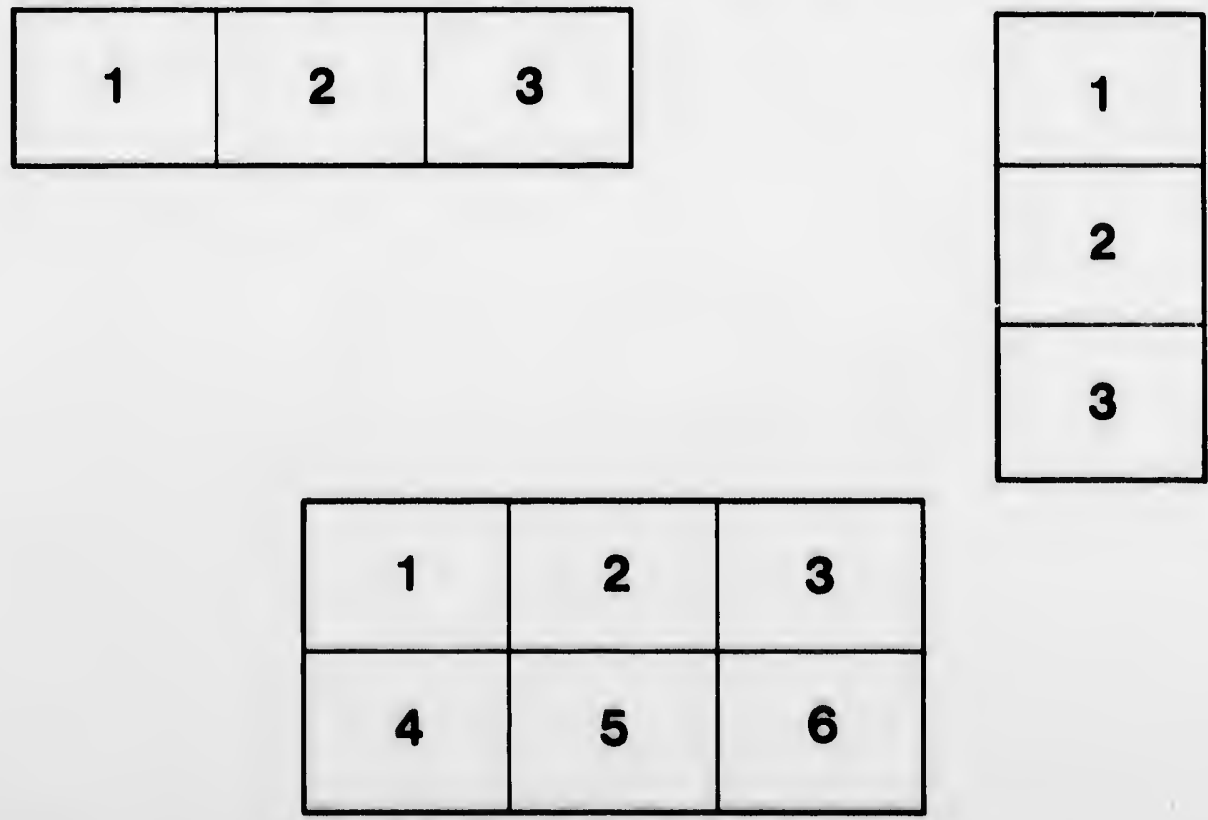


\title{
BRIEF NOTES OF A TRIP TO POINT PELEE, WITH ADDITIONS TO OUR LIST OF CANADIAN BUTTERFLIES.
}

\author{
BY THE EDITOR.
}

During the summer of 1882 , we paid a flying visit to Point Pelee, in company with some friends who were interested in Botany. This point of land extends directly south into Lake Erie, near the eastern boundary of the County of Essex, and is among the most southerly points in the Province of Ontario. On the west side of the Point the land is chiefly marsh until near the extremity, and is a prolific hunting ground for sportsmen in search of water-fowl; it is also a breeding place for millions of Neuropterous insects. The east shore is sandy, and between this and the marsh are several farms and a considerable area of uncultivated arable land more or less covered with woods.

We reached Essex Centre, on the Canada Southern Railway, the nearest point of access by rail, at $7 \mathrm{p}$. $\mathrm{m}$., on the 28 th of June, where we hired a vehicle and driver for three or four days, and drove that evening over an excellent road 18 miles to Leamington. The night was spent here and an early start made the next morning for the Point. A drive of about three miles brought us to the base of the Point, and after a journey of about eight miles farther, we reached the upper extremity.

The day was warm and pleasant, and during the last portion of this drive we saw more Dragon-flies and other Neuropterous insects than we had ever seen in our lives before; they literally swarmed everywhere, especially in sunny spots. They flew in our faces and buzzed about our ears as we were driving, and settled on our clothing in considerable numbers. After catching all that could be conveniently carried, we amused ourselves by swinging the net in different directions, catching a few dozen and then letting them fly again. Among the most numerous species were Libellula basalis, L. trimaculata, L. exusta, Diplax intacta, and $D$. rubicundula, with some others undetermined. During the drive there also floated past us on rapid wing several specimens of Papilio cresphontes and one or two $P$. marcillus, but they flew with the prevailing wind directly over the swamp, where pursuit was impracticable. As we passed a sunny spot in the woods, approaching the end of our joumey, a small dark-colored insect was seen hovering about some flowers growing

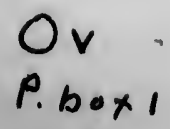


by the road-side, which from its peculiar jerky flight, was evidently a Thecla. A brief chase resulted in its capture, when it proved to be Thecla smilacis Boisd., = auburniana Harris, never before, to our knowledge, recorded as occurring in Canada. As we approached the extremity of the Point, we left the swamps behind us and with them the multitudinous hosts of the larger Neuropterous insecrs, but several of the smaller species were present, associated with Dipterous insects, in prodigious numbers, flying in clouds from every tree and bush we touched, the vibration of their many wings causing a loud roar or buzz. The sides of houses and barns were so thickly covered with them as to almost hide the wood they rested on, but they did not venture inside the buildings.

The next day was unfavorable for collecting; the rain poured in torrents until early in the afternoon. As soon as it had ceased, we wandered several miles along the sandy roads and shores, and found many interesting plants and trees, but there were very few insects on the wing, excepting those belonging to the Neuroptera, which were everywhere in abundance. Late in the afternoon, while beating about among the bushes on the sand hills on the eastern shore, a yellow butterfly started up which at first was thought to be a pale $C$. philodice, but there was something unusual about its appearunce and manner of flight which led us to pursue it until captured. Imagine our surprise when we found it to be a female specimen of Terias Mexicana Boisd.

In W. H. Edwards' Catalogue of Diurnal Lepidoptera, Thecla smilacis Boisd. is said to be found in the Atlantic States, Mississippi Valley and Texas, while the localities given for Terias Mexicana are Texas to Arizona; California, occasionally in Kansas and Nebraska.

Since both these buttertlies are new to our Canadian lists, we append descriptions of them.

Thecla smilacis is thus described by Boisduval : "Upper side blackish brown, with a pale whitish spot near the middle of the costal edge; the secondaries have two thin tails as in the analagous species.

"Under side greenish, often washed with a little reddish, with a transverse whitish ray sinuous on the primaries, tortuous on the secondaries, bordered in front by a ferruginous tint. Between this ray and the base, the secondaries have another short transverse sinuous ray of the same color. The extremity is marked by two or threc ashy crescents, of which the intermediary is black in front, and the third in a line with two or three 
small ferruginous spots, more or less distinct. The anal palette is black, and near the fringe there is a small white marginal line.

"Larva, which feeds on Smilax, is green, with the head and feet blackish. It has four rows of red spots, of which the two dorsal are formed of smaller spots, and one on each side composed of spots somewhat larger.

"Chrysalis grayish-brown, with the abdomen more clear and reddish."

Harris, who regarded this species as distinct from smilacis, thus describes it under the name of auburniana, and Harris' description agrees more closely with the specimens captured by us than does that of Boisduval. Harris says : "The outermost of the tails of this insect is very short, and often nothing remains of it but a little tooth on the edge of the wing. It varies considerably in color; the females are generally deep brown above, but sometimes the wings are rust-colored or tawny in the middle, as they always are in the males; the oval opaque spot which characterizes the latter sex is ochre-yellow. Upon the under side the wings in both sexes are green, the anterior pair tinged with brown from the middle to the inner edge; externally next to the fringe they are all margined by a narrow wavy white line, bordered internally with brown; this line on the fore wings does not reach the inner margin; on the hind wings it consists of six spots arranged in a zigzag manner, and the last spot next to the inner margin is remote from the rest; besides these there are on the same wing $r$ three more white spots bordered with brown between the zigzag band and the base; and between the same band and the margin three black spots, behind the middle one of which is a rust-red spot with a black centre. The wings expand from $1 x^{1}$ to $I_{1}^{2}$ inch. This pretty species is found on the mouse-ear (Gnaphalium plantagineum) in May, and on the flowers of the spearmint in August."

"Terias Mexicana Boisd. Boisd. Spec. Gén. 679. Figured on pl. 3, C. fig. I, of Boisd. Spec. Gén.

"Wings brilliant citron yellow; primaries with a black border at the extremity, rather wide, ending squarely at the internal angle, showing near the middle a rather deep quadrangular sinus; the outer edge slightly sinuate, and whitish ; secondaries, with the middle of the exterior edge prolonged to a prominent angle, in the form of a tail ; a black border of moderate width, a little dentated on its internal side, not reaching the 
internal angle; costal edge washed with orange yellow, mingling with the ground color.

"Under side of the primaries pale citron yellow, with a black central point, the edge intersected with brown points ; the outer edge reddish near the fringe.

"Under side of secondaries yellow, sprinkled with ferruginous atoms, with a blackish central point; edge intersected with ferruginous points, and marked near the external angle with a spot of the same color; the posterior half having four or five other spots of the same color, of which two or three are in a line, and tending to form a transverse band; the middle of the outer edge more or less washed with ferruginous.

"Female differs from the male in the upper side being yellowish white, with a wider border, the quadrangular sinus more profound; the anterior edge of the secondaries widely orange yellow, and below, three ferruginous posterior spots form on the secondaries a narrow, transverse, ferruginous band.

"Texas-Louisiana-Mexico."

Among the other insects taken were Papilio cresphontes, P. turnus, P. troilus, Colias philodice, Terias lisa, Argynnis cybcle, Phyciodes tharos, Pyrameis huntera, P. atalanta, Anchyloxypha numitor, Pholisora catullus, Eudsmus tityrus, Eudryas grata, Leucania unipuncta, Lucanus lentus and Macrodactylus subspinosus. The latter species was very common on the flowers of the tulip tree (Liriodendron tulipifera), which was then blooming freely; also on the sour gum or Pepperidge tree (Nyssa multi. flora).

The next morning we started early on our return journey and reached Essex Centre in time to take the afternoon train home. Had the weather been favorable we should doubtless have reaped a much richer harvest.

\section{THE HAIRY LARVA AND THEIR PARASITES.}

BY FREDERICK CLARKSON, NEW YORK CITY.

It is generally acknowledged by Entomologists that the hairy larvæ, such as the Arctians and their allies, very commonly escape parasitic attack, a circumstance attributable to the fact, that in order to permit the deposit of ova, these caterpillars must be discovered by the parasites in favorable postures, or else worried by them into such, that the spines separating, give the only opportunity for the insertion of the ovipositor. 